\title{
HEAVY METALS LEVEL OF MEDICINAL PLANTS COLLECTED FROM SELECTED DISTRICT IN KHYBER-PAKTHTUNKHWA, PAKISTAN
}

\author{
MUHAMMAD IDREES ${ }^{1}$, SHAZIA RAFIQ ${ }^{1}$, SAMI ULLAH ${ }^{2}$, F. AKBAR JAN ${ }^{1 *}$, M. NAEEM \\ KHAN $^{1}$, FAZAL MABOOD $^{3}$ \\ ${ }^{I}$ Department of Chemistry, Bacha Khan University Charsadda, Khyber-Pakhtunkhwa, 24420 Pakistan \\ ${ }^{2}$ Department of Botany, University of Peshawar, Peshwar Khyber Pakhtunkhwa, Pakistan \\ ${ }^{3}$ Department of Biological Sciences and Chemistry, University of Nizwa, Nizwa-616, Oman
}

*corresponding author:fazal_akbarchem@yahoo.com

Manuscript received: December 2017

\begin{abstract}
The toxic metal contents of common medicinal plants collected from Dir Lower a hilly area in KPK Pakistan were analysed. All the selected heavy metals were detected in almost all the samples. Co concentration ranged from $0.24-4.58 \mathrm{ppm}, \mathrm{Cr}$ from 0.59 - $5.1 \mathrm{ppm}, \mathrm{Cu}$ from 0.86 - $3.17 \mathrm{ppm}, \mathrm{Mn}$ from 7.52 - $23.38 \mathrm{ppm}$, Ni from 0.96 - $4.78 \mathrm{ppm}, \mathrm{Pb}$ from $13.45-2.33$ ppm, Sb from 7.44 - 19.69 ppm, Zn from 2.42 - 48.86 ppm, Fe from 27.68 - 139.20 ppm, respectively in different herbal plants. Amongst the screened plants samples Boehraria diffusa was found to be heavily contaminated followed by Verbascum thapsus, Melia azedarach L., Berberis lyceum Royle, Nicotiana affinis and Datura alba. The analysed metals concentrations were found higher than the WHO permissible limits in majority of plant samples. The order of distribution with respect to concentration of the selected metals was $\mathrm{Fe}>\mathrm{Zn}>\mathrm{Mn}>\mathrm{Pb}>\mathrm{Co}>>\mathrm{Cu}>\mathrm{Cr}>\mathrm{Ni}>\mathrm{Sb}$.
\end{abstract}

\section{Rezumat}

A fost analizat conținutul de metale grele din plantele medicinale provenite din zona deluroasă Dir Lower, Pakistan. Toate metalele grele selectate au fost detectate în aproape toate eșantioanele. Concentrațiile au variat astfel: Co: $0,24-4,58$ ppm, Cr: 0,59 - 5,1 ppm, Cu: 0,86 - 3,17 ppm, Mn: 7,52 - 23,38 ppm, Ni: 0,96 - 4,78 ppm, Pb: 13,45 - 2,33 ppm, Sb: 7,44 - 19,69 ppm , Zn: 2,42 - 48,86 ppm, Fe: 27,68 - 139,20 ppm. Dintre probele de plante testate Boehraria diffusa a fost puternic contaminată urmată de Verbascum thapsus, Melia azedarach L., Berberis lyceum Royle, Nicotiana affinis și Datura alba. Concentrațiile metalelor analizate au fost găsite mai mari decât limitele admise de OMS în majoritatea probelor de plante. Ordinea distribuției în ceea ce privește concentrația metalelor selectate a fost: $\mathrm{Fe}>\mathrm{Zn}>\mathrm{Mn}>\mathrm{Pb}>\mathrm{Co}>\mathrm{Cu}>\mathrm{Cr}>\mathrm{Ni}>$ $\mathrm{Sb}$.

Keywords: heavy metals, herbal plants, Lower Dir, atomic absorption spectroscopy

\section{Introduction}

Herbal medicines have been used since ancient times for curing different ailments. Nowadays the knowledge of medicinal plants has gained a considerable interest due to the high cost and side effects of allopathic drugs. The pharmacists are trying to synthesize herbal derived drugs [1, 10]. Plants uptake non-essential metal ions on the same mechanism as uses for essential metal ions plants and thus transport them to the aerial parts or by atmospheric deposition thereby contaminating the food chain [2-5]. Though some metals in trace amount are vital for human body, their excessive accumulation can cause serious health hazards. Medicinal plants and herbal preparations must be evaluated for their standards according to the WHO guidelines. The determined total elemental concentrations are important to estimate maximum intake of metals from herbal medicine.
Medicinal plants should be properly checked for quality and safety. The main purpose of the present study was to quantify about 9 selected heavy metals in 28 different medicinal plants collected from the district lower Dir in Khyber-Pakhtunkhwa. As no data on the metal contents and ethnomedicinal uses of the selected herbal plants was available in the study area, so this study was designed with the aim to provide a scientific database for traditional practitioners as well as for pharmaceutical industries.

\section{Materials and Methods}

Description of the study area

Dir Lower is located in the north-western part of Khyber-Pakhtunkhwa, Pakistan and is topographically dominated by mountains which are part of ranges/ branches of Hindukush and Hindu Raj. 
FARMACIA, 2018, Vol. 66, 5

The mountains have a rich flora of herbal plants. Medicinal plant's diversity and their use by the local people determined the selection of the study area. A total of 28 different medicinal plant belonging to 15 families were collected for the study.

\section{Plant collection}

A total of 28 different herbal plants species were collected from different localities in Dir Lower and identified in the Department of Botany, Bacha Khan University, Charsadda, Pakistan. Plants samples were stored in polythene bags tagged properly, and brought to the Laboratory. The samples were washed with distilled water, separated into leaf, stem and roots. These parts were then oven dried at $65^{\circ} \mathrm{C}$ for $24 \mathrm{~h}$ and grounded into the powdered form.

Acid digestion of plant samples

One gram powdered sample of plant leaves was soaked in $10 \mathrm{~mL}$ mixture of $\mathrm{HClO}_{4}$ and $\mathrm{HNO}_{3}$ (1:4) and left for an overnight. On the next day the soaked samples were heated on the hot plate till the appearance of white fumes. The solution was filtered and adjusted to the final volume of $50 \mathrm{~mL}$ and kept in plastic bottles for analysis [6]. Analysis of the samples for heavy metals

The concentrations of nine heavy metals $(\mathrm{Cr}, \mathrm{Cu}, \mathrm{Fe}$, $\mathrm{Ni}, \mathrm{Pb}, \mathrm{Mn}, \mathrm{Co}, \mathrm{Sb}$ and $\mathrm{Zn}$ ) were analysed using Atomic Absorption Spectrophotometer (PerkinElmer Analyst PinAAcleTM 900T equipped with an AS-900 graphite furnace auto sampler and with deuterium background corrector) in Advanced Research laboratory, Department of Chemistry, Bacha Khan University Charsadda, Pakistan [7]. For ensuring precision and accuracy, certified reference materials (CRMs) of all metals were analysed.

Statistical analyses

Principle Component Analysis (PCA), Correlation Analysis (CA) and Cluster analysis, were performed using the software package SPSS version 13.

\section{Results and Discussion}

Heavy metals levels of herbal plants

The present study reported 28 different medicinal plants belonging to 15 families where their distribution in the same district is given in Figure 1.

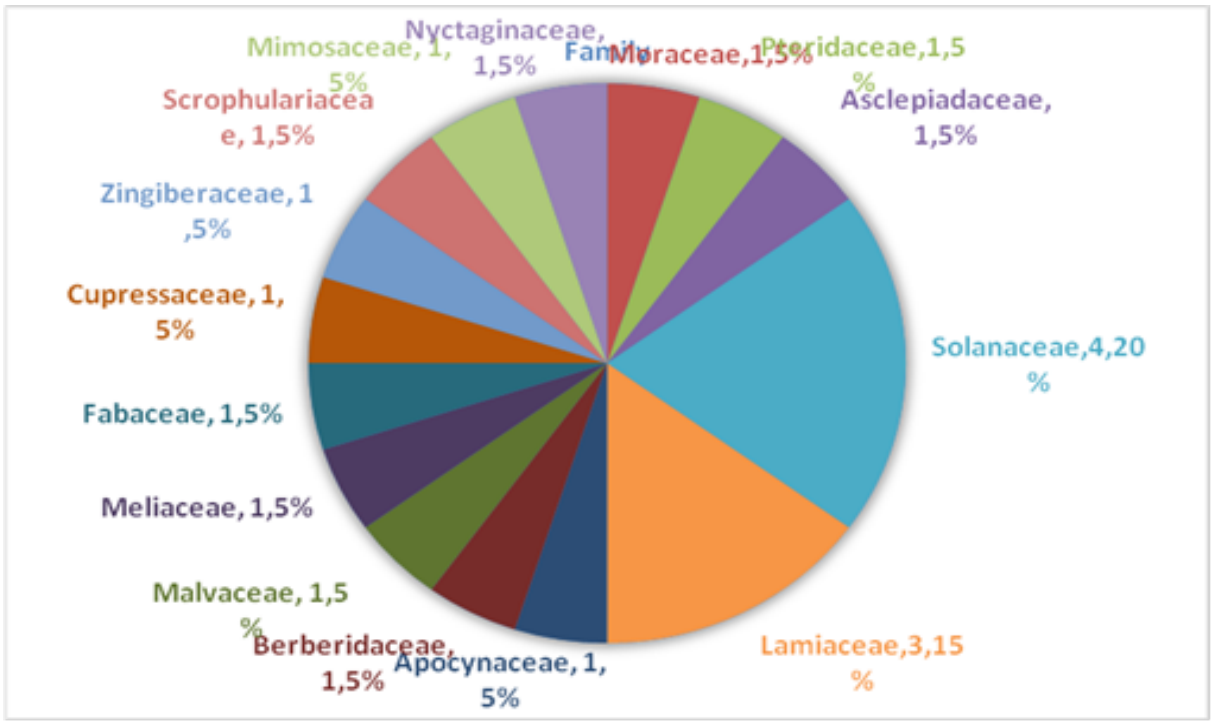

Figure 1.

Plants' distribution and their percentage in Dir Lower

Table I summarizes the mean concentrations of the selected heavy metals in different herbal plants species. Co is an essential element and play a role in the synthesis of vitamin B12. It also activates the production of red blood cells and control anaemia in the pregnant women. Excessive uptake of Co usually hampers RNA and DNA synthesis, promote leaf fall, premature leaf closure, inhibit greening and reduces shoot weight [8]. The highest $5.58 \mathrm{ppm}$ concentration of $\mathrm{Co}$ was found in Boehraria diffusa, followed by $4.46 \mathrm{ppm}$ in Withania sominifera and $4.40 \mathrm{ppm}$ in Verbascum thapsus and
Prosopis spicigera. There is no WHO/FAO established criteria for permissible limits of $\mathrm{Co}$, in medicinal plants.

Chromium plays an important role in the metabolism of cholesterol, fat, and glucose and regulates blood sugar level while at high concentration it is toxic and carcinogenic. The WHO permissible value for chromium concentration in raw herbal materials is $2 \mathrm{ppm}$. The permissible limit set by $\mathrm{FAO} / \mathrm{WHO}$ in edible plants is $0.02 \mathrm{ppm}$. In case of all the selected plant samples $\mathrm{Cr}$ concentration was higher than the permissible limit. The highest 
FARMACIA, 2018, Vol. 66, 5

concentration of $\mathrm{Cr}$ was found in Verbascum thapsus, $5.10 \mathrm{ppm}$, followed by $4.67 \mathrm{ppm}$ in Nicotiana affinis, $4.58 \mathrm{ppm}$ in Withania sominifera and $4.15 \mathrm{ppm}$ in Morus nigra. $\mathrm{Cu}$ has been found to help in the oxidation of $\mathrm{Fe}^{+2}$ to $\mathrm{Fe}^{+3}$ during haemoglobin formation, and in the formation of bones, myelin sheaths in the nervous systems, and assists in the absorption of iron from the gastrointestinal tract. At high concentrations $\mathrm{Cu}$ causes respiratory diseases, metal fumes fever, hair and skin discolorations and dermatitis in human beings [9-11]. Copper concentration was found within WHO permissible limit $(3.00 \mathrm{ppm})$ in the selected plants samples, with the exception of Foeniculum vulgare which was found to contain higher concentrations of $\mathrm{Cu}, 3.17 \mathrm{ppm}$, followed by $2.92 \mathrm{ppm}$ in Ficus carica and $2.81 \mathrm{ppm}$ in Melia azedarach L.

Table I

Metals concentration (ppm) in different medicinal plant species collected from District Dir Lower

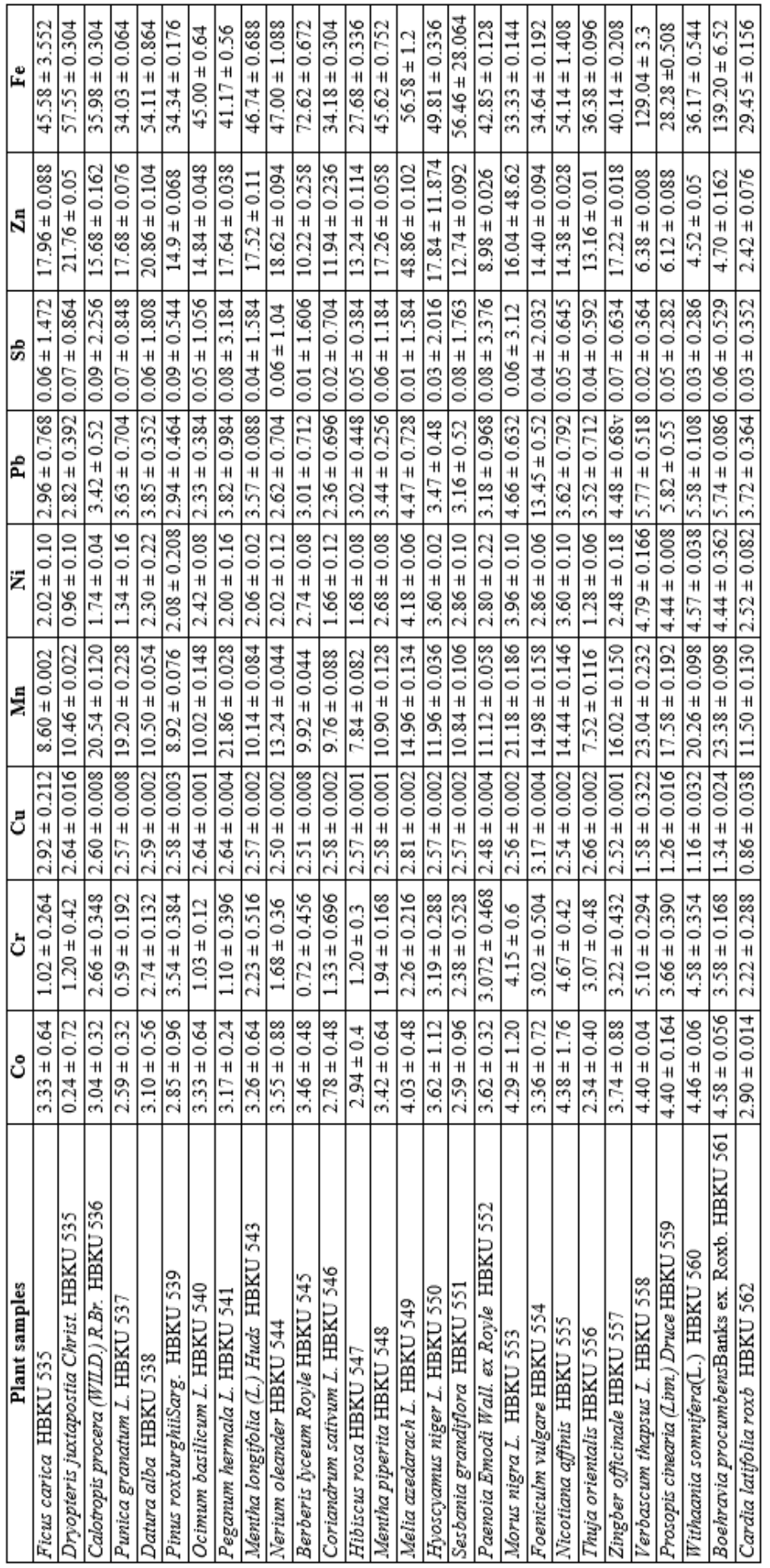


Manganese is also an essential element and play a role in carbohydrates and lipids metabolism. At high concentrations Mn causes loss of body weight and vision, skin irritation, heart and liver failures, adverse effects on the lungs, central nervous system (CNS) function and mood [12]. In all medicinal plant samples the concentration of Mn was higher than the WHO permissible limit (2 ppm). Mn concentration was found low in all the plants in comparison to previous studies [13]. The highest concentration (23.38 ppm) of $\mathrm{Mn}$ was found in Boehraria diffusa followed by $23.045 \mathrm{ppm}$ in Verbascum thapsus, $21.86 \mathrm{ppm}$ in Peganum harmala and $21.18 \mathrm{ppm}$ in Morus nigra. This can be attributed to the Mn enriched rocks of the study area.

Nickel plays a vital role in the production of insulin. Excessive intake of $\mathrm{Ni}$ causes nickel itch, disturbance of the nasal cavities, lungs, as a carcinogenity and hypersensitivity [14]. Ni concentration was also found higher than the WHO permissible limit $(1.63 \mathrm{ppm})$ with the exception of Dryopteris juxtapostia Christ, Punica grantaum and Thuja orientalis which were found to have $\mathrm{Ni}$ concentration within permissible limits. The highest concentration of $\mathrm{Ni}$ (4.78 ppm) was found in Verbascum thapsus followed by 4.57 ppm in Withania sominifera and $4.44 \mathrm{ppm}$ in Boehraria diffusa and Prosopis spicigera Lead has no specific functions in humans and plants and is therefore nonessential element. In all collected samples the levels of $\mathrm{Pb}$ did not exceed the recommended limits of 10 ppm except for Foeniculum vulgare which was found to have accumulated $13.45 \mathrm{ppm}$ of $\mathrm{Pb}$.

Literature has shown that high $\mathrm{Sb}$ concentrations in soil inhibit the early growth of plants. Antimony concentration was also found higher than WHO permissible limit $(0.005 \mathrm{ppm})$. The highest concentration $(0.09 \mathrm{ppm})$ was found in Hyoscyamus insanus, Calotropis procera and Pinus roxburghii Sarg. followed by $0.08 \mathrm{ppm}$ in Peganum harmala L., Sesbania grandiflora and Paenoia emodi Wall. ex Royle. Zinc is an important constituent of plasma and plays a role in normal growth, DNA synthesis, bone formation, brain development, wound healing, insulin action and tissue repair.

At high levels $\mathrm{Zn}$ is neurotoxic. Zinc concentration was found within WHO/FAO permissible limits (27.4 ppm) except for Melia azedarach L., which was found to have the highest $\mathrm{Zn}$ contents (48.86 ppm), followed by $21.76 \mathrm{ppm}$ in Dryopteris juxtapostia Christ and 20.86 ppm in Datura alba. In case of all collected medicinal plant species $\mathrm{Zn}$ concentration varied over a wide range. This can be attributed to the fact that its bio-accessibility rate is facilitated due to the presence of different substances such as citric acid and ascorbic acid. Though $\mathrm{Fe}$ is an essential element, at high concentrations causes tissues damage and some other diseases in humans. The concentrations of $\mathrm{Fe}$ in medicinal herbs were maximum as compared to other elements. Iron concentration was also found higher than WHO permissible limit (20 ppm) in almost all the selected plant species. The highest concentration (139.20 $\mathrm{ppm}$ ) of Fe was found in Boehraria rocumbens followed by $129.04 \mathrm{ppm}$ in Verbascum thapsus and 72.62 ppm in Berberis lyceum Royle.

There was found a large variation of the elemental contents for different plants from the same location, therefore the elemental contents must be checked in particular for regularity purposes because the maximum elemental contents of medicinal plants have the potential to substantially increase the exposure, uptake and body concentrations of trace elements. Moreover, due to the differences in the metals' content of pharmaceutical raw materials from the toxicology point of view there is a dire need to monitor the presence of different elements and other contaminations. Many factors such as differences in plant physiology, soil properties, agricultural management practices, pollution inputs and prevailing climate can account differential metal accumulation in plants.

\section{Conclusions}

All the selected metals were found higher than the WHO permissible limits in the majority of the plants. Foeniculum vulgare was found to have accumulated the highest concentration of $\mathrm{Pb}$ (13.4 ppm), Verbascum thapsus the highest concentration of $\mathrm{Cr}(5.10 \mathrm{ppm})$ and $\mathrm{Fe}(129.04 \mathrm{ppm})$, respectively. The present study provides a baseline data step for the researchers to collect and analyse medicinal plants from other regions for the determination and quantification of toxic metals for safety purposes.

\section{References}

1. Adamczyk D, Jankiewicz B, Effects of thiuram on uptake of copper, zinc and manganese by Valeriana officinalis L. Pol J Environ Stud., 2008; 17(5): 823826.

2. Gasser U, Klier B, Kuhn AV, Steinhoff B, Current findings on the heavy metal content in herbal drugs. Pharm Eur Sci Notes, 2009; 1: 37-50.

3. Baye H, Hymete A. Lead and cadmium accumulation in medicinal plants collected from environmentally different sites. Bull Environ Contam Toxicol., 2010; 84: 197-201.

4. Chilian A, Popescu IV, Radulescu C, Cimpoca GV, Bancuta R, Bancuta I, Gheboianu A, Effect of zinc supplementation on growth, biochemical process and yield in Zeamays. J Sci Arts, 2011; 17: 471-486. 
5. Das KK, Das SN, Dhundasi SA, Nickel, its adverse health effects and oxidative stress. Ind $J$ Med Res., 2008; 128: 412-425.

6. Jan FA, Ishaq M, Khan S, Ihsanullah I, Ahmad I, Shakirullah M, A comparative study of human health risks via consumption of food crops grown on waste-water irrigated soil (Peshawar) and relatively clean water irrigated soil (Lower Dir). Hazrd Mater., 2010; 179: 612-621.

7. Gulab H, Mahmood M, Ali S, Ja FA, Assessment of heavy metals in various parts of plants, soil and air of some selected areas of district Charsadda, Pakistan. Carpath J Earth Environ Sci., 2015; 10: 219-224.

8. Hoareau L, DaSilva EJ, Medicinal plants: a reemerging health aid. Electron J Biotechnol., 1999; 2: $56-70$.

9. Konno B, Integration of traditional medicine with modern medicine. EHNRI, Addis Ababa. 2004; 3-9.
10. Velescu BS, Anuţa V, Niţulescu GM, Olaru OT, Orțan A, Ionescu D, Ghica MV, Drăgoi CM, Dinu Pîrvu CE, Pharmaceutical assessment of Romanian crops of Anthriscus sylvestris (Apiaceae). Farmacia, 2017; 65(6): 824-831.

11. Kiran YK, Mir AK, Rabia N, Mamoona M, Hina F, Paras M, Element content analysis of plants of genus Ficus using atomic absorption spectrometer. Afr J Pharm Pharmacol., 2011; 5(3): 317-321.

12. Murray RK, Granner DK, Mayes PA, Rodwell VW, Harper's biochemistry, $25^{\text {th }}$ Ed. McGraw-Hill, Health Profession Division, USA 2000.

13. Mahmood A, Mahmood A, Tabassum A, Ethnomedicinal survey of plants from District Sialkot. Pak J Appl Pharm., 2011; 02: 212-220.

14. Shah A, Niaz A, Ullah N, Rehman A, Akhlaq M, Zakir M, Comparative study of heavy metals in soil and selected medicinal plants. $J$ Chem-NY, 2013; 2013: 1- 5 . 